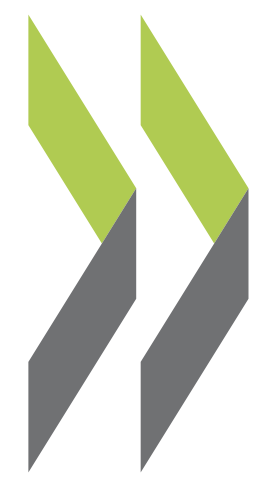

OECD Economics Department Working Papers No. 1361

International tax planning Stéphane Sorbe, and fixed investment Asa Johansson 
Organisation de Coopération et de Développement Économiques

Organisation for Economic Co-operation and Development

06-Feb-2017

ECONOMICS DEPARTMENT

English - Or. English

\section{INTERNATIONAL TAX PLANNING AND FIXED INVESTMENT}

ECONOMICS DEPARTMENTS WORKING PAPERS No. 1361

\section{By Stéphane Sorbe and Åsa Johansson}

OECD Working Papers should not be reported as representing the official views of the OECD or of its member countries. The opinions expressed and arguments employed are those of the author(s).

Authorised for publication by Christian Kastrop, Director, Policy Studies Branch, Economics Department.

All Economics Department Working Papers are available at www.oecd.org/eco/workingpapers.

JT03408633

Complete document available on OLIS in its original format

This document and any map included herein are without prejudice to the status of or sovereignty over any territory, to the delimitation of international frontiers and boundaries and to the name of any territory, city or area. 
OECD Working Papers should not be reported as representing the official views of the OECD or of its member countries. The opinions expressed and arguments employed are those of the author(s).

Working Papers describe preliminary results or research in progress by the author(s) and are published to stimulate discussion on a broad range of issues on which the OECD works.

Comments on Working Papers are welcomed, and may be sent to OECD Economics Department, 2 rue André Pascal, 75775 Paris Cedex 16, France, or by e-mail to eco.contact@oecd.org.

All Economics Department Working Papers are available at www.oecd.org/eco/workingpapers.

This document and any map included herein are without prejudice to the status of or sovereignty over any territory, to the delimitation of international frontiers and boundaries and to the name of any territory, city or area.

The statistical data for Israel are supplied by and under the responsibility of the relevant Israeli authorities. The use of such data by the OECD is without prejudice to the status of the Golan Heights, East Jerusalem and Israeli settlements in the West Bank under the terms of international law.

Latvia was not an OECD Member at the time of preparation of this publication. Accordingly, Latvia does not appear in the list of OECD Members and is not included in the zone aggregates.

\section{(C) OECD (2016)}

You can copy, download or print OECD content for your own use, and you can include excerpts from OECD publications, databases and multimedia products in your own documents, presentations, blogs, websites and teaching materials, provided that suitable acknowledgment of OECD as source and copyright owner is given. All requests for commercial use and translation rights should be submitted to rights@oecd.org 


\section{ABSTRACT/RÉSUMÉ}

\section{International tax planning and fixed investment}

This paper assesses how international tax planning affects real business investment by multinationals. Earlier studies have shown that corporate taxes reduce business investment. This paper shows that tax planning multinationals are less sensitive to corporate taxes than other firms in their investment decisions. This is presumably because tax planning multinationals do not face the full tax burden associated with their investments, since they shift part of the resulting profits to lower-tax rate countries. On average across industries, a 5 percentage point corporate tax rate increase is found to reduce investment by $5 \%$ in the long term. In industries with a strong presence of multinationals with profit-shifting opportunities, this effect is halved. These results obtained with industry-level data are confirmed by a firm-level analysis. Consistently with these results, the investment of tax planning multinationals is found to be more sensitive to taxes when strong rules against tax planning are in place.

JEL classification codes: E22, F23, H26.

Key words: Investment, corporate tax, multinational tax planning, anti-avoidance rules.

$* * * * * * * * * * * *$

\section{Planification fiscale internationale et investissement des entreprises}

Cet article évalue comment la planification fiscale internationale affecte l'investissement réel des entreprises multinationales. Des études antérieures ont montré que l'impôt sur les sociétés réduit l'investissement des entreprises. Cet article montre que les multinationales engagées dans la planification fiscale sont moins sensibles à l'impôt sur les sociétés que les autres entreprises dans leurs décisions d'investissement. C'est sans doute parce que les multinationales engagés dans la planification fiscale ne sont pas confrontées à la charge fiscale totale associée à leurs investissements, car elles transfèrent une partie des bénéfices qui en résultent dans des pays à taux d'imposition plus faible. En moyenne dans les différents secteurs, une augmentation du taux d'imposition des sociétés de 5 points de pourcentage réduirait l'investissement de 5\% sur le long terme. Dans les secteurs avec une forte présence des multinationales avec des opportunités de transferts de bénéfices, cet effet est réduit de moitié. Ces résultats obtenus avec des données au niveau sectoriel sont confirmés par une analyse au niveau de l'entreprise. En cohérence avec ces résultats, l'investissement des multinationales engagées dans la planification fiscale serait plus sensible aux taxes lorsque des règles strictes contre la planification fiscale sont en place.

Classification JEL: E22, F23, H26.

Mots clés: investissement, impôt sur les sociétés, planification fiscale multinationale, règles anti-évitement. 


\section{TABLE OF CONTENTS}

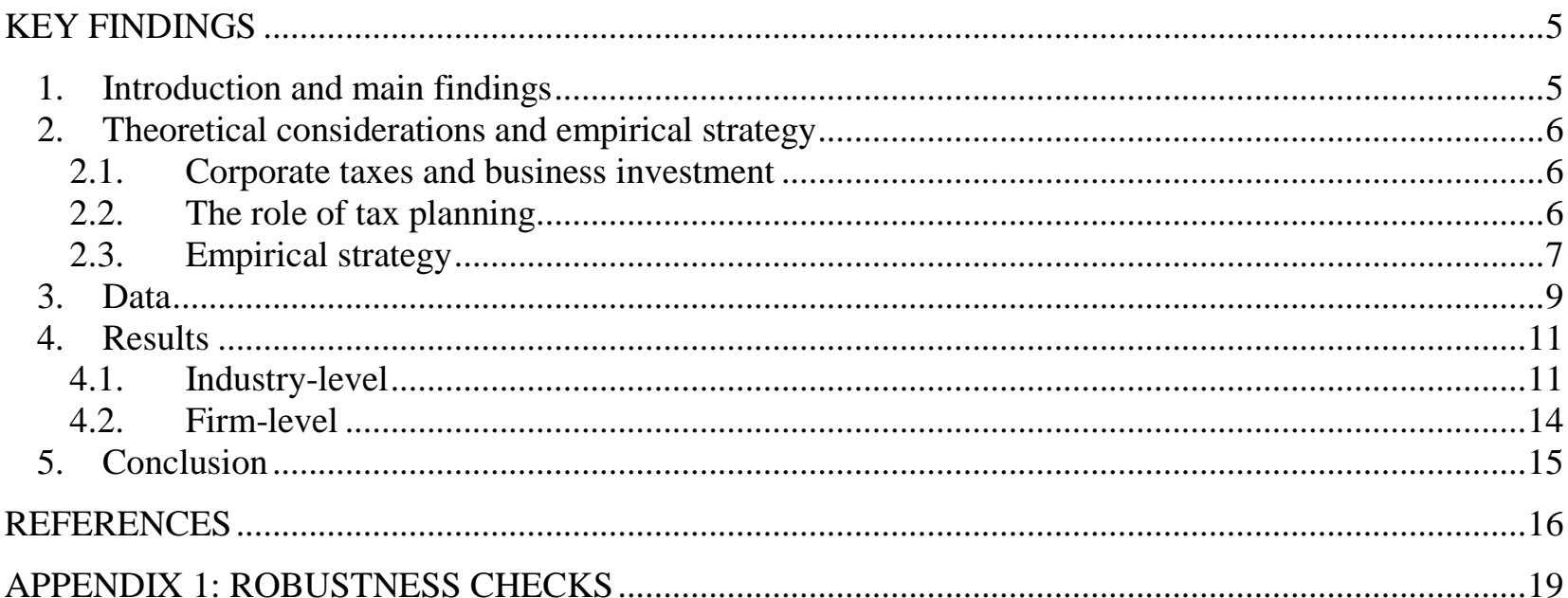

\section{Tables}

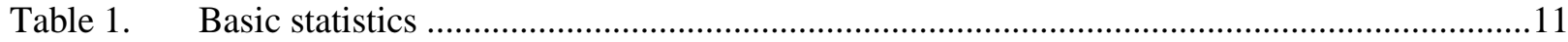

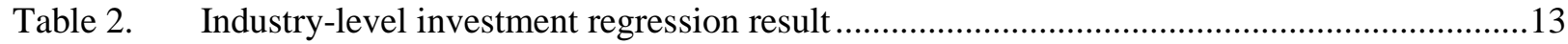

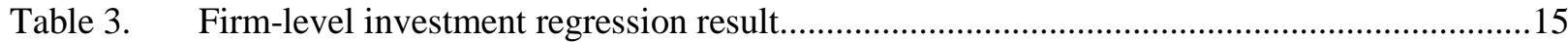

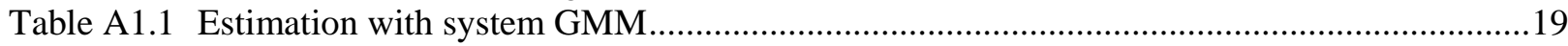

Table A1.2 Using the average rather than marginal effective tax rate .................................................20

\section{Figures}

Figure 1. Tax planning reduces the effect of corporate taxes on investment. 


\title{
INTERNATIONAL TAX PLANNING AND FIXED INVESTMENT
}

\author{
By Stéphane Sorbe and Åsa Johansson ${ }^{1}$
}

\section{KEY FINDINGS}

- This study confirms previous evidence that corporate taxes have a negative effect on business investment. A 5 percentage point increase in the effective corporate tax rate is found to be associated with about $5 \%$ lower investment in the long term on average across industries.

- In industries with a strong presence of multinational enterprises (MNEs) having profit-shifting opportunities, investment is found to be significantly less sensitive to changes in corporate tax rates. For example, in an industry at the $75^{\text {th }}$ percentile of the distribution of profit-shifting opportunities, the effect of corporate taxes on investment is halved relative to the median industry.

- In countries with strong "anti-avoidance" rules against tax planning, the tax sensitivity of investment in profitshifting intensive industries is stronger than in countries with weaker rules.

- Overall, this suggests that international tax planning reduces the effect of corporate taxation on the investment of tax-planning MNEs and its location. However, this is achieved at the cost of additional distortions as compared with a situation in which corporate tax rates would be cut across the board.

\section{Introduction and main findings}

1. Corporate income taxes affect business investment in several ways. By reducing the after-tax return on investment, high corporate taxes can lead firms to reject certain investment projects or reduce their scale, thus reducing the overall level of investment (OECD, 2009; Arnold et al., 2011). Corporate taxes also influence the allocation of investment across industries and countries (Fatica, 2013). All else equal, higher-tax rate countries attract less international investment than lower-tax rate countries, although corporate taxes are only one among many determinants of investment location (Skeie, 2016; Hajkova et al., 2006; Feld and Heckemeyer, 2011).

2. This paper explores whether the effect of corporate taxes on investment is influenced by international tax planning, which is also known as Base Erosion and Profit Shifting (BEPS) (OECD, 2013). The idea is that tax planning allows multinational enterprises (MNEs) to reduce their tax burden, for example by shifting profits to lower-tax rate or no-corporate-tax countries (Johansson et al., 2016a). As a result, the return on investment of an MNE entity in a high-tax rate country is only partially taxed (or not taxed at all) in this country. Reflecting this, tax-planning MNEs are expected to be less sensitive to corporate taxes in their investment decisions than non-tax-planning firms. Indeed, existing single-country studies focusing on US and German MNEs suggest that tax planning can affect the tax sensitivity of investment (Grubert, 2003; Overesch, 2009). The purpose of this paper is to assess this effect systematically across a wide range of countries.

1 Stéphane Sorbe (stephane.sorbe@dgtresor.gouv.fr) was with the OECD Economics Department when this paper was produced and Åsa Johansson (asa.johansson@oecd.org) is at the OECD Economics Department. The authors would like to thank Christian Kastrop, Giuseppe Nicoletti, Jean-Luc Schneider, from the Economics Department, and Øystein B. Skeie (was with the OECD Economics Department when this paper was produced) for their valuable comments and suggestions and Sarah Michelson for excellent editorial support (also from the Economics Department). The paper has also benefitted from comments by OECD staff, members of Working Party No. 1 of the OECD Economic Policy Committee and members of Working Party No. 2 of the OECD Committee of Fiscal Affairs. 
3. This paper confirms that corporate taxes have a negative impact on investment and shows that this negative impact is smaller among tax-planning MNEs than other firms. The analysis is based on a large sample of industry and firm-level data for OECD and G20 countries. A 5 percentage point increase in the effective marginal corporate tax rate is found to be associated with a reduction in investment by about $5 \%$ in the long term on average across industries. This effect is lower in industries with a high concentration of MNE entities with profit-shifting incentives, i.e. entities facing a higher statutory corporate tax rate than the average in their MNE group. This definition of profit-shifting incentives is in line with the accompanying paper on the assessment of tax planning (Johansson et al., 2016a). For an industry with a strong presence of MNE entities with profit-shifting incentives $\left(75^{\text {th }}\right.$ percentile of the distribution), the tax sensitivity of investment is nearly halved as compared to the median industry. Results obtained at the firm-level are consistent with these industry-level results.

4. The estimation results also suggest that strong anti-avoidance rules against tax planning (e.g. strict transfer pricing documentation requirements and interest deductibility rules, see Johansson et al., 2016b) increase the tax sensitivity of investment in industries with a strong concentration of profit-shifting MNEs. This confirms that tax planning affects the tax sensitivity of investment. Thus, tax planning opportunities may allow higher-tax rate countries to retain attractiveness as investment destinations for taxplanning MNEs, but this would come at the cost of tax distortions and losses in tax revenues.

\section{Theoretical considerations and empirical strategy}

\section{1. $\quad$ Corporate taxes and business investment}

5. The effect of corporate income taxes on business investment is widely discussed in the literature since the seminal papers by Jorgenson (1963) and Hall and Jorgenson (1967). Studies generally find adverse effects of corporate taxes on investment, although with different estimates of magnitude (for reviews, see e.g. Hasset and Hubbard, 2002; Djankov et al., 2010; European Commission, 2013). In line with other empirical studies, recent OECD work suggests that a reduction in the corporate tax rate by 5 percentage points (from 35\% to 30\%) would increase the investment-to-capital ratio by $1-2 \frac{1}{2}$ percent in the long term (Vartia, 2008; Arnold et al., 2011).

6. The related question of the influence of corporate taxes on the allocation of foreign investment across countries is also widely studied in the empirical literature. A meta-analysis by Feld and Heckemeyer (2011) suggests that a one percentage point increase in the corporate tax rate differential between two countries results in a decrease by about $3 \%$ in the gross bilateral foreign direct investment (FDI) stock in the higher-tax rate country. With additional controls for policy determinants other than corporate taxes, Hajkova et al. (2006) find a tax sensitivity of about $1.5 \%$. These elasticities reflect both the tax sensitivity of "real" investments and of artificial cross-borders financial flows induced by tax planning, which are impossible to disentangle in existing bilateral FDI data (Skeie, 2016).

\subsection{The role of tax planning}

7. Without differences in corporate tax systems and rates across countries, investment would be determined and located purely according to economic rates of return (assuming no other policy differences between countries). However, tax rates and systems differ. This can create distortions, which may result in resources not being allocated to the most efficient projects or countries (Auerbach, 1983).

8. Tax-planning opportunities alter the after-tax return on investments and therefore influence MNEs' investment decisions (see e.g. Grubert and Slemrod, 1998; Grubert, 2003; Desai et al., 2005). Tax planning is generally thought to lessen the distortions induced by corporate taxes (Hong and Smart, 2010; Dharmapala, 2014). This is because tax planning lowers the effective tax rate on investment, especially in 
high-tax countries. As a result, tax planning reduces the difference between pre-tax and after-tax return on investment, as well as cross-country differences in effective tax rates on investments. These reductions in tax differentials should tend to lower distortions from corporate taxes on firms' investment decisions, although the fact that tax planning reduces the tax burden non-uniformly across firms is a potential source of additional tax distortions. For example, tax planning tends to give an advantage to firms strongly engaged in it, such as large MNEs, especially those that are intensive in intangible assets or debt, over other firms (Johansson et al., 2016a). This advantage can distort competition between firms by allowing certain MNEs to increase their market power at the expense of other firms and benefit from higher pricecost mark-up rates (Sorbe and Johansson, 2016).

9. Few empirical studies investigate the effect of international tax planning on the link between corporate taxes and investment. Using German firm-level data from the Bundesbank, Overesch (2009) shows that the investment of foreign-owned entities in Germany is positively associated with corporate tax rate cuts in the home country of these entities. The idea is that foreign-owned German entities are likely to shift part of their profits to their home country because of Germany's relatively high tax rate. Assuming such profit shifting, a corporate tax rate cut in the home country increases the after-tax return on an investment project in Germany, which would explain the positive investment reaction. ${ }^{2}$ Hence, the finding by Overesch (2009) can be interpreted as an indication that, in their investment decisions, MNEs react to the tax rate in the country where profits are shifted and not only to the rate in the country where they invest.

10. Using tax data for the United States, Grubert (2003) shows that R\&D-intensive MNEs have more international tax planning opportunities than other MNEs. This reflects the role of intangible assets in taxplanning schemes, which is explained by the difficulty to benchmark their price (and the associated income) against market prices. In a second step, Grubert (2003) shows that R\&D-intensive MNEs are more likely than other MNEs to invest in countries with either very high or very low tax rates. Investments in very-low-tax countries are interpreted as serving in the setting up of tax-planning schemes. Investment in very-high-tax countries can be attractive for R\&D-intensive MNEs, since tax-planning allows them to avoid most of the high tax burden that other firms have to face in these countries. This is an indication that tax-planning behaviour affects real investment decisions of firms.

\subsection{Empirical strategy}

11. The approach in this paper is to measure the tax sensitivity of investment across firms (or industries) depending on their tax-planning intensity. The hypothesis is that the investment of tax-planning firms (industries) is less sensitive to changes in corporate tax rates than the investment of other firms (industries). The empirical strategy is to estimate an investment equation inspired from a neo-classical investment model where investment depends on the user cost of capital (Hall and Jorgenson, 1967). This equation is used to isolate the effect of corporate taxes, which is one key component of the user cost. The next step is to test if the effect of taxes varies across firms or industries depending on their tax-planning intensity. With the available data, investment is best measured at the industry level, while tax-planning opportunities are best identified at the firm-level. Against this background, the analysis is undertaken both at the industry and the firm-level. The two approaches yield consistent results.

2. Other factors may also be at play. For example, Becker and Riedel (2012), based on a sample of European MNEs from the Amadeus database, suggest that a tax rate cut in the home country can create a positive income shock for the MNE group, which may lead to the group to increase its investment in all countries. 


\subsubsection{Industry-level approach}

12. The effect of corporate taxes on investment is estimated with a similar strategy as in Vartia (2008). The investment rate, i.e. the ratio of investment to the stock of capital, is regressed over a lagged term, to capture investment dynamics, and the effective corporate tax rate. The effective tax rate reflects both the rate applying to the profits generated by an investment and the effect of tax deductions related to capital depreciation. The effective tax rate is an important component of the overall user cost of capital, along with the net financing cost of investment (Fatica, 2013). In this study, the effect of taxes on investment is estimated separately from that of financing costs. ${ }^{3}$ The effect of financing costs could not be identified empirically and is not included in the baseline specification. ${ }^{4}$ Finally, the effect of tax planning is estimated by interacting the effective tax rate with the share of firms having profit-shifting incentives in each industry and country. The estimated equation is as follows:

$$
\begin{aligned}
& \frac{I_{c, i, t}}{K_{c, i, t-1}}=\alpha \frac{I_{c, i, t-1}}{K_{c, i, t-2}}+\beta E T R_{c, t-1}+\gamma E T R_{c, t-1} \times \text { ProfitShifting }_{c, i, 2009} \\
& +\theta \text { VAgrowth }_{c, i, t-1}+\delta_{c, i}+\delta_{t}
\end{aligned}
$$

Where $I_{c, i, t}$ is business fixed investment in country $c$, industry $i$ and year $t$, and $K_{c, i, t}$ the resulting capital stock at the end of year $t$. ETR $R_{c, t}$ is the forward-looking effective corporate tax rate in country $c$ and year $t$. The baseline specification uses the marginal effective tax rate (EMTR), while the average effective tax rate (EATR) is used as a robustness check. Both rates are a priori relevant to investment decisions. EATRs are most relevant to the decision to invest or not, while EMTRs are relevant to the size of the investment (Devereux and Griffith, 2003). ProfitShifting ${ }_{c, i, 2009}$ is the share of MNEs with profit-shifting incentives among top-100 firms (ranked by turnover) in industry $i$ and country $c$. This share is extracted from firmlevel data in year 2009, where coverage is the most extensive. An entity is considered as having profitshifting incentives if it faces a higher tax rate in its home country than the average (unweighted) in its corporate group, in line with the profit-shifting analysis in Johansson et al. (2016a). The coefficient $\beta$ reflects the average tax sensitivity across industries, while $\gamma$ reflects whether industries with a high concentration of profit-shifting MNEs are more sensitive than other industries. ${ }^{5}$ VAgrowt $_{c, i, t}$ is valueadded growth in volume terms. Fast-growing industries are expected to have higher investment rates. Finally, $\delta_{c, i}$ and $\delta_{t}$ are respectively fixed-effects for country interacted with industry and time.

13. The equation is estimated with ordinary least squares (OLS). Nickell (1981) shows that this can lead to inconsistent estimates as the lagged dependent variable can be correlated with the fixed-effects and thus with the disturbance term. This bias diminishes when the estimation period is long. The estimation period in this paper (1997-2009) is shorter than in Vartia (2008), but not excessively short suggesting that the bias is likely to be moderate. As a robustness check, the model is also estimated with a system generalised method of moments (GMM) estimator, using lagged levels and first differences of the

3. In contrast, Vartia (2008) estimates jointly the effect of taxes and financing costs by combining them into a single user cost of capital variable, which does not allow to separate the effect of taxes from other costs.

4. This is a common finding in the empirical literature (e.g. Caballero, 1999; Sharpe and Suarez, 2014). In this paper, it may reflect the roughness of the measure of net financing costs. Net financing costs were proxied by the interest rate on long-term government bonds, net of capital depreciation (the depreciation rate takes into account the average share of equipment and buildings in the assets of each industry). However, financing costs for firms can differ widely from government bond rates. See Gilchrist and Zakrajsek (2007) for a firm-specific measure of financing costs and its link to investment.

5. A possible refinement could be to allow for non-linearities, to reflect the earlier finding by Grubert (2003) that tax planning MNEs are more likely than other MNEs to invest in countries with either very high or very low tax rates. 
dependent variable as instruments (Appendix 1). It is unclear which estimator (OLS or GMM) is best, since Ziliak (1997) shows that GMM estimations can also induce biases in the case of weak instruments leading to weak identification.

14. A refinement is introduced to assess the role of anti-avoidance rules. These rules have been shown to be associated with reduced profit shifting (Johansson et al., 2016a). The hypothesis tested in this study is whether strong rules are also associated with a higher tax-sensitivity of investment among potential tax planners. For example, if a firm has high profit shifting incentives (i.e. a link to a low-tax country) its investment is expected to be relatively tax-insensitive. However, if strong anti-avoidance rules are in place, the firm may be prevented from shifting profit to a low-tax country and its investment should be more tax-sensitive than in the absence of rules. To test this hypothesis, the term $E T R_{c, t-1} \times$ ProfitShifting $g_{c, i, 2009}$ in equation (1), which measures the tax-sensitivity of firms with tax planning incentives, is interacted with a measure of anti-avoidance strength.

\subsubsection{Firm-level approach}

15. The approach at the firm level is similar to the industry level. The estimated equation is as follows:

$$
\begin{gathered}
\frac{I_{f, c, i, t}}{K_{f, c, i, t-1}}=\beta E T R_{c, t-1}+\gamma E T R_{c, t-1} \times \text { ProfitShifting }_{f, i, c, t} \\
+\theta \text { VAgrowth }_{c, i, t-1}+\delta_{f}+\delta_{t}
\end{gathered}
$$

16. Where $I_{f, c, i, t}$ is the investment of firm $f$ operating in country $c$, industry $i$ and year $t$, measured as the change in fixed assets (at book value), corrected for depreciation (also at book value). $K_{f, c, i, t}$ is the capital stock at the end of the year, proxied by fixed assets. In contrast to the industry-level analysis, no lagged dependent variable is included. This is because the observation period is shorter than at the industry-level reflecting limitations in the coverage of the available firm-level database. The effective tax rate and value-added growth variables are identical to the industry-level analysis. In particular, value-added growth is not firm-specific, since there is an important number of firms for which value-added is not available in the firm-level database. ProfitShifting $f_{f, c, i, t}$ represents profit shifting incentives, as measured by the difference between the statutory tax rate in country $i$ and year $t$ and the average (unweighted) among the countries where the MNE group of $f$ operates. A positive (negative) difference corresponds to incentives to shift (receive) profit. $\delta_{f}$ and $\delta_{t}$ are firm and time fixed-effects, which control for all firmspecific (and therefore also industry and country-specific) characteristics influencing investment rates.

\section{Data}

17. The source of industry-level data is the World Input-Output Database (July 2014 vintage). This database contains industry-level accounts for 35 industries and 40 countries (mainly OECD and G20) over 1995-2011. The investment rate at the industry level is computed as real gross fixed capital formation (i.e. nominal gross fixed capital formation deflated by the gross fixed capital formation price index) divided by lagged real capital stock. Value-added growth is measured as the growth rate of gross value added, in volume terms. Extreme values of the investment rate (negative or above 50\%) and of value added growth (annual growth below $-30 \%$ or above $30 \%$ ) are excluded, as they are likely to result from exceptional events or series breaks. Public services (i.e. industries with NACE codes above 75) are excluded from the sample.

18. The source of firm-level data is the ORBIS database. The ORBIS database contains financial account data and ownership information of firms worldwide. The database is commercialised by Bureau 
Van Dijk, based on information from different sources (e.g. chambers of commerce, local public authorities or credit institutions). It was processed by the OECD Statistics Directorate to improve consistency across countries and remove reporting errors and implausible values (Pinto Ribeiro et al., 2010; Ragoussis and Gonnard, 2012). An additional processing was implemented for this project to identify corporate groups by iterating on the firm-level ownership information available in ORBIS (Appendix 2 of Johansson et al., 2016a, Menon, 2016) and to further remove implausible values (Appendix 3 of Johansson et al., 2016a). Still, ORBIS data has limitations, as coverage for certain countries (most notably the United States) is limited and some links between MNE entities may be missing (Johansson et al., 2016a).

19. The investment rate at the firm level is proxied by the change in fixed assets net of capital depreciation and divided by lagged fixed assets, i.e. $\frac{I_{t}}{K_{t-1}}=\frac{\text { FIXED_ASSETS }_{t}-\text { FIXED }_{\text {ASSETS }}+1}{\text { FIXED_ASSERSECIST }_{t-1}}$. This measure of the investment rate is similar to Gal (2013). ${ }^{7}$ Netting for depreciation implies that the numerator of this measure corresponds only to the new fixed assets created or bought by the firm in year $t$. This is because both fixed assets and depreciation are measured at book value and thus consistent with each other in the ORBIS database. Still, one caveat is that book value depreciation is generally more rapid than economic depreciation. ${ }^{8}$ This means that the denominator (FIXED_ASSETS $\left.{ }_{t-1}\right)$ is generally lower than the economic value of the capital stock, which results in an upwards distortion in the investment rate. Nevertheless, this distortion is unlikely to be related to the variables of interest (tax rates, links to other countries) and therefore to bias the results. Consistently with the industry-level analysis, extreme values of the investment rate (negative or above 50\%) and of value added growth (below -30\% and above 30\%) are excluded.

20. A MNE entity is considered to have profit-shifting incentives if it faces a higher tax rate than the unweighted average among the countries where the MNE group operates. In the firm-level analysis, profitshifting incentives are measured as this tax rate difference between the home country and the group average, computed from ORBIS. The industry-level analysis relies on the share of firms with profitshifting incentives among the top-100 firms (ranked by turnover) in each industry and country, extracted from ORBIS in 2009 (industry-country pairs with less than 100 observations in ORBIS are excluded from the analysis). This is the year where coverage is the most extensive in the available financial and ownership data and also the year which was used in the identification of MNE groups (Appendix 2 of Johansson et al., 2016a, Menon, 2016). One limitation is that profit-shifting incentives of an entity may have changed over the sample period, for example if the country where it operates has cut its corporate tax rate or if the corporate structure of its MNE group has changed over the period.

21. The source of forward-looking effective tax rates (both marginal and average) is the Oxford Centre for Business Taxation. These tax rates derive from modelling a hypothetical investment project on a discounted cash flow basis and taking account of all the relevant tax provisions, based on the DevereuxGriffith method (Devereux and Griffith, 2003). By construction, they do not include the effect of tax planning.

6. Data in ORBIS is originally expressed in euros, even for countries with a different currency. To avoid that exchange rate movements affect the measure of the investment rate, all variables are converted to the relevant local currency, using the exchange rate provided in the ORBIS database.

7. One difference is that Gal (2013) uses tangible fixed assets rather than total (i.e. tangible and intangible) fixed assets. Using tangible fixed assets ensures that intangible investment is excluded from the measure, but at the cost of being less consistent with the measure of capital depreciation in ORBIS, which generally includes both the depreciation of tangible assets and the amortisation of intangible assets.

8. A third concept is depreciation for tax purposes, which differs from economic and book depreciation. 
22. The strength of anti-avoidance rules against international tax planning and withholding taxes is measured on a 0-8 scale taking into account five key dimensions of the rules: (i) the comprehensiveness of documentation and disclosure requirements on transfer prices; (ii) the existence and strictness of rules limiting interest deductibility (thin capitalisation and interest-to-earnings rules); (iii) the existence of a general anti-avoidance rule (GAAR); (iv) the existence of a controlled foreign-company (CFC) rule; and (v) withholding taxes on interest, dividends and royalties, taking into account tax treaties. As rules are complex and country-specific, the classification inevitably relies on simplifying assumptions (see Johansson et al., 2016b for details). For example, enforcement practices (e.g. frequency of tax audits, penalties in case of non-compliance) are not captured. Another limitation is that the analysis relies on the anti-avoidance strength in $2005,{ }^{9}$ which is towards the middle of the sample period, and does not take into account that the strength of rules may have changed over the period.

23. The final industry-level sample covers 30 industries in 29 countries over 1997-2009. The panel is unbalanced, reflecting data limitations of the WIOD database (for certain country-industry pairs, data for some years is not available) and ORBIS (for certain country-industry pairs, there are less than 100 observed firms in 2009). The firm-level sample consists of about 50,000 observations of MNE entity accounts, from 19 OECD countries, over 2000-10. Other OECD and G20 countries could not be included due to data limitations, but ownership links to countries outside the sample are taken into account in the identification of MNE groups and the computation of the tax variable measuring profit shifting incentives. The firm-level panel is unbalanced since coverage in ORBIS varies overtime. Only firms observed for at least five years over the period are kept in the sample. ${ }^{10}$ Basic statistics are presented in Table 1.

Table 1. Basic statistics

Panel A: Industry-level sample

\begin{tabular}{lccccc}
\hline Variable & $\begin{array}{c}\text { Number of } \\
\text { observations }\end{array}$ & Mean & $\begin{array}{c}\text { Standard } \\
\text { deviation }\end{array}$ & Minimum & Maximum \\
\hline Investment rate & 6,087 & $12.2 \%$ & $6.6 \%$ & $0.7 \%$ & $48.7 \%$ \\
Value-added growth rate & 6,087 & $3.2 \%$ & $7.5 \%$ & $-29.2 \%$ & $29.9 \%$ \\
Effective marginal tax rate (EMTR) & 6,087 & $17.5 \%$ & $7.4 \%$ & $-3.4 \%$ & $43.9 \%$ \\
Share of top-100 firms with profit-shifting incentives & 6,087 & 0.21 & 0.21 & 0.00 & 0.92 \\
Anti-avoidance strength (0-8 classification) & 6,087 & 4.3 & 1.8 & 1 & 8 \\
\hline
\end{tabular}

Panel B: Firm-level sample

\begin{tabular}{lccccc}
\hline Variable & $\begin{array}{c}\text { Number of } \\
\text { observations }\end{array}$ & Mean & $\begin{array}{c}\text { Standard } \\
\text { deviation }\end{array}$ & Minimum & Maximum \\
\hline Investment rate & 50,368 & $13.6 \%$ & $11.5 \%$ & $0.0 \%$ & $50.0 \%$ \\
Value-added growth rate & 50,368 & $2.4 \%$ & $5.9 \%$ & $-29.7 \%$ & $29.9 \%$ \\
Effective marginal tax rate (EMTR) & 50,368 & $17.8 \%$ & $4.8 \%$ & $-3.4 \%$ & $38.6 \%$ \\
Tax variable (home - average group difference) & 50,368 & 0.01 & 0.04 & -0.17 & 0.20 \\
\hline
\end{tabular}

\section{Results}

\subsection{Industry-level}

24. The results confirm the negative link between corporate taxes and investment. A 5 percentage point increase in the effective marginal corporate tax rate (EMTR) is associated with lower investment by

9. The classification was only compiled for the years 2005 and 2014.

10. Keeping only firms observed over the full period to obtain a balanced panel would reduce the number of observations too drastically for the regression analysis. 
about $5 \%$ in the long term (and about $2 \%$ in the short term) on average across industries (Table 2, column 1). ${ }^{11}$ This effect is strong compared to existing estimates. For example, it is about twice as strong as the effect estimated in Arnold et al. (2011) for a tax rate cut from 35\% to 30\% for an average firm. This difference may reflect the different estimation strategy (Arnold et al. (2011) estimate the effect of taxes jointly with other components of the user cost of capital) and possibly the broader coverage of countries in this study. As expected, rapid value-added growth in an industry is associated with higher investment rates.

25. The presence of MNEs with profit-shifting incentives is found to reduce significantly the tax sensitivity of investment (column 2). The estimated coefficients imply that in an industry with a strong presence of MNEs with profit-shifting incentives $\left(75^{\text {th }}\right.$ percentile of the distribution), the long-term investment reaction to a 5 percentage point EMTR increase is a $2.5 \%$ decline, which is about half the reaction in the median industry (Figure 1). ${ }^{12}$ Similarly, in an industry with half as many profit-shifting MNEs as in the average industry, the tax sensitivity of investment would be about $30 \%$ higher than in the average industry. ${ }^{13}$ Overall, this suggests that international tax planning reduces the effect of corporate taxes on investment and its location. However, this is achieved at the cost of additional distortions (e.g. uneven playing field between tax-planning MNEs and other firms) as compared with a situation in which corporate tax rates were cut across the board (see Sorbe and Johansson, 2016).

26. Strong anti-avoidance rules are found to increase the tax sensitivity of investment in industries with a strong presence of MNEs with profit-shifting incentives (column 3). At the $75^{\text {th }}$ percentile of the distribution of industries on profit-shifting incentives, moving from the moderate anti-avoidance strength (i.e. 3-4 on a 0-8 scale) to a relatively strong stance (5-6 on the 0-8 scale) is associated to about tripling the tax sensitivity of investment. ${ }^{14}$ The magnitude of this effect appears very large, but it should be interpreted with caution as it is estimated from a complex triple interaction term (i.e. a variable multiplying the effective tax rate with the number of MNEs with profit-shifting incentives and anti-avoidance strength) and as the tax variable taken individually is no longer significant in this regression (although the three variables are jointly significant). ${ }^{15}$ In addition, the anti-avoidance classification is limited and does not take into account detailed country-specific provisions or enforcement of existing rules.

11. A 5 percentage point increase in the EMTR is associated with a lower investment rate by $5 \times 0.051=$ 0.255 percentage point in the short term and $5 \times \frac{0.051}{1-0.578}=0.604$ percentage point in the long term. Given an average investment rate of $12 \%$ in the sample (Table 2), this corresponds to lower investment by $\frac{0.604}{12}=5 \%$ in the long term.

12. The average industry in the sample has 21 entities with profit shifting incentives (Table 1). The median industry has 12 . An industry at the 75th percentile of the distribution has 32 . The coefficients estimated in column (2) imply that the long-term reaction to a 5 percentage point EMTR increase is a $4.8 \%$ decline in the median industry, a $3.8 \%$ decline in the average industry and a $2.5 \%$ decline in the industry at the 75 th percentile.

13. In an industry with half the average number of MNE entities with profit shifting incentives (i.e. 10.5 entities with profit-shifting incentives instead of 21), the estimated coefficients imply that the long-term reaction to a 5 percentage point increase in the EMTR would be a $5.1 \%$ rather than $3.8 \%$ decline.

14. This result is robust to using a 0-6 anti-avoidance classification excluding GAARs and CFC rules. As the design of these rules is very country-specific, the 0-8 classification only reflects the existence or nonexistence of a rule, which is simplistic. (see Johansson et al., 2016b). The fact that results are robust to excluding GAARs and CFC rules suggests that this classification choice is not driving the results.

15. This non-significance may reflect that the tax sensitivity of investment is unevenly distributed across firms. The investment of some firms is very tax sensitive (e.g. MNEs without profit-shifting incentives or in countries with strong anti-avoidance rules), while other firms are much less sensitive. The specification in column (3) captures separately the high tax sensitivity of the most sensitive firms. This may explain why 
ECO/WKP(2016)85

Table 2. Industry-level investment regression result

\begin{tabular}{|c|c|c|c|}
\hline & (1) & (2) & (3) \\
\hline & Baseline & $\begin{array}{l}\text { With profit shifting } \\
\text { incentives }\end{array}$ & $\begin{array}{l}\text { With profit shifting } \\
\text { incentives and } \\
\text { anti-avoidance } \\
\text { strength }\end{array}$ \\
\hline Dependent variable & \multicolumn{3}{|c|}{ Investment rate: $\mathrm{I}(\mathrm{t}) / \mathrm{K}(\mathrm{t}-1)$} \\
\hline Year dummies & yes & yes & yes \\
\hline Country*industry fixed effects & yes & yes & yes \\
\hline Lagged investment rate & $\begin{array}{c}0.578^{* * *} \\
{[0.036]}\end{array}$ & $\begin{array}{c}0.577^{* * *} \\
{[0.036]}\end{array}$ & $\begin{array}{c}0.574^{\star * *} \\
{[0.036]}\end{array}$ \\
\hline $\begin{array}{l}\text { Lagged value-added growth (at country- } \\
\text { industry level) }\end{array}$ & $\begin{array}{l}0.027^{* * *} \\
{[0.007]}\end{array}$ & $\begin{array}{l}0.027^{* * *} \\
{[0.007]}\end{array}$ & $\begin{array}{c}0.026^{* * *} \\
{[0.007]}\end{array}$ \\
\hline $\begin{array}{l}\text { Lagged effective marginal tax rate } \\
\text { (EMTR) }\end{array}$ & $\begin{array}{c}-0.051^{* * *} \\
{[0.015]}\end{array}$ & $\begin{array}{c}-0.039^{* * *} \\
{[0.014]}\end{array}$ & $\begin{array}{l}-0.005 \\
{[0.019]}\end{array}$ \\
\hline $\begin{array}{l}\text { Lagged EMTR } \times \text { Share of MNEs with } \\
\text { profit shifting incentives }\end{array}$ & & $\begin{array}{l}0.126^{\star *} \\
{[0.057]}\end{array}$ & $\begin{array}{c}0.136^{\star *} \\
{[0.054]}\end{array}$ \\
\hline $\begin{array}{l}\text { Lagged EMTR } \times \text { Share of MNEs with } \\
\text { profit shifting incentives } \times \text { Anti- } \\
\text { avoidance strength }\end{array}$ & & & $\begin{array}{l}-0.133^{\star *} \\
{[0.058]}\end{array}$ \\
\hline Observations & 6,087 & 6,087 & 6,087 \\
\hline R-squared & 0.408 & 0.409 & 0.41 \\
\hline AdjR2 & 0.407 & 0.407 & 0.408 \\
\hline $\mathrm{F}$ & 34.11 & 32.49 & 32.89 \\
\hline
\end{tabular}

All regressions are ordinary least squares (OLS). ${ }^{* * *}$ indicates significance at the $1 \%$ level, ${ }^{* *}$ at the $5 \%$ level and ${ }^{*}$ at the $10 \%$ level. Robust standard errors corrected for clustering at the country-year level are presented under brackets. The interacted variables are mean-centred, so coefficients can be interpreted as the effects at the mean. The sample consists of 30 industries in 29 OECD and G20 countries over 1997-2009. Investment and value-added data is taken from the World Input-Output Database (WIOD). The forward-looking effective marginal tax rate (EMTR) is from the Oxford Centre for Business Taxation. The number of MNEs with profit shifting incentives is extracted from ORBIS. Anti-avoidance strength is the classification presented in Johansson et al., (2016b).

27. Results are broadly robust to estimating with system GMM rather than OLS. When estimating with system GMM, the long-term tax sensitivity of investment remains broadly unchanged. The effect of profit-shifting intensity on the tax sensitivity is slightly lower, but no longer statistically significant (Table A1.1).

28. When replacing effective marginal tax rates by effective average tax rates, the effect of taxes on investment remains negative but it is not statistically significant. Still, the effect of profit-shifting MNEs remains positive and significant in this case (Table A1.2).

the tax variable taken individually is not significant in column (3) while it was in the specification of columns (1) and (2). 
Figure 1. Tax planning reduces the effect of corporate taxes on investment

Estimated long-term change in investment after a 5 percentage point increase in the corporate tax rate ${ }^{1}$

Panel A: Across industries

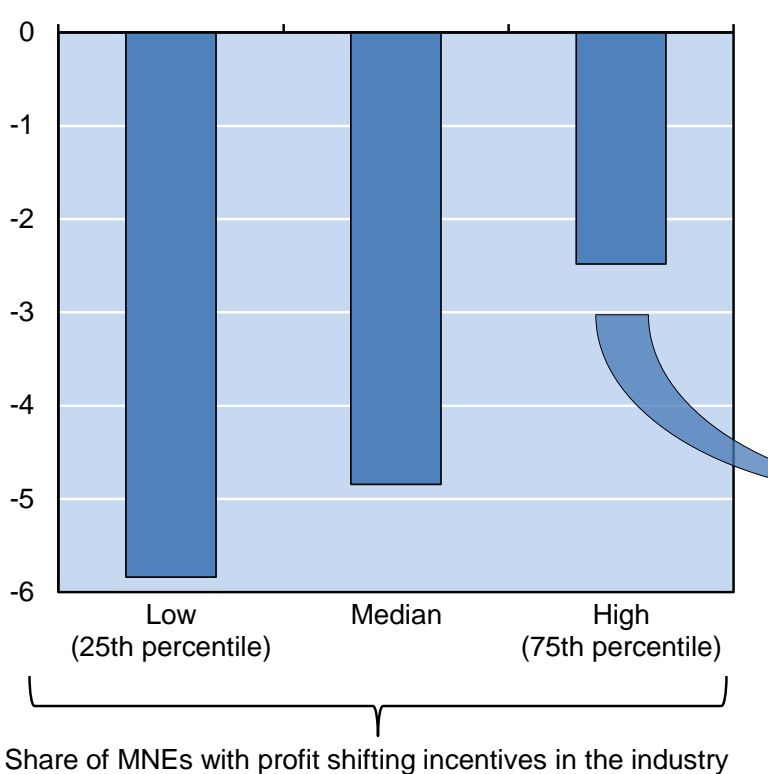

Panel B: Strength of rules against tax planning: industries with high MNE share $\left(75^{\text {th }}\right.$ percentile)

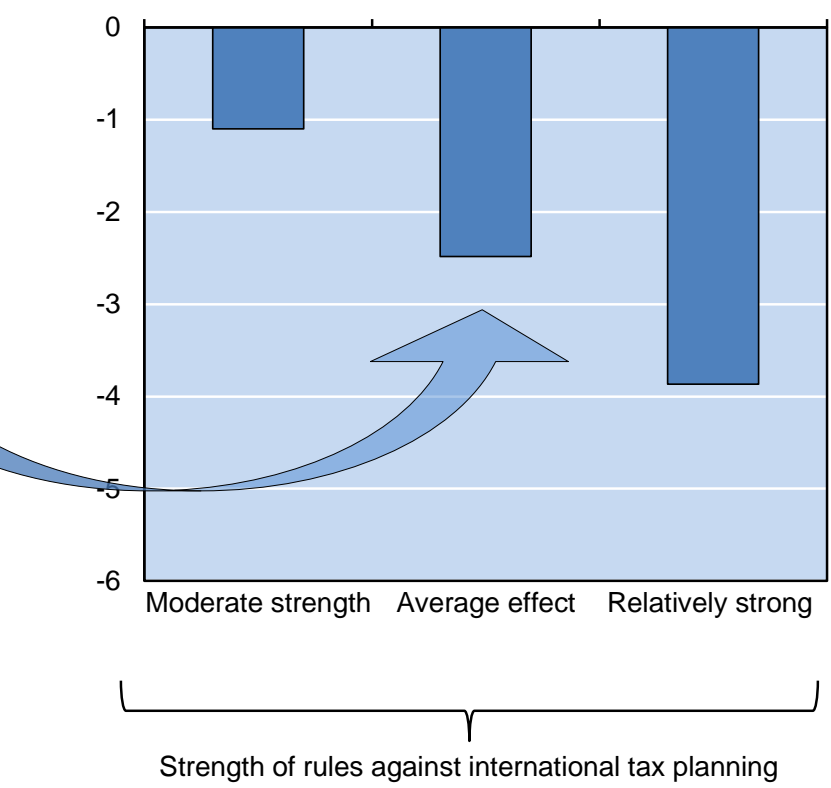

1. The corporate tax rate considered is the marginal forward-looking effective tax rate. All differences in the reaction of investment to tax rate changes are significant at a $5 \%$ level.

\subsection{Firm-level}

29. The results at the firm level are broadly consistent with industry-level results, although the estimated sensitivity of investment to corporate tax rates is slightly lower (Table 3). In the firm-level regression, a 5 percentage point increase in the EMTR is associated with 0.5 percentage point lower investment rate, which at the average investment rate in the ORBIS sample (14\%) corresponds to $3.7 \%$ lower investment in the short and the long term. ${ }^{16}$ In line with the industry-level analysis, high profitshifting incentives are found to reduce the tax sensitivity of investment. However, the magnitude of the effect cannot be compared with the firm-level analysis, since the variable measuring profit-shifting incentives has a different nature. It is a tax rate differential in the firm-level analysis, while it is the share of MNEs with a positive tax rate differential in the industry-level analysis.

16. The short-term and long-term effects are the same since there is no lagged dependent variable among explanatory variables in the firm-level regression. 
Table 3. Firm-level investment regression result

\begin{tabular}{|c|c|c|}
\hline \multirow[b]{3}{*}{ Dependent variable } & (1) & (2) \\
\hline & Baseline & $\begin{array}{l}\text { Profit-shifting } \\
\text { incentives }\end{array}$ \\
\hline & \multicolumn{2}{|c|}{ Investment rate (firm level) } \\
\hline Firm fixed-effects & yes & yes \\
\hline Year fixed-effects & yes & yes \\
\hline Lagged EMTR & $\begin{array}{c}-0.104^{* *} \\
{[0.046]}\end{array}$ & $\begin{array}{c}-0.144^{* * *} \\
{[0.049]}\end{array}$ \\
\hline Lagged EMTR $\times$ Profit-shifting incentives & & $\begin{array}{c}0.504^{\star *} \\
{[0.239]}\end{array}$ \\
\hline $\begin{array}{l}\text { Lagged value added growth (at the country-industry } \\
\text { level) }\end{array}$ & $\begin{array}{c}0.033^{\star * *} \\
{[0.011]}\end{array}$ & $\begin{array}{c}0.033^{* * *} \\
{[0.011]}\end{array}$ \\
\hline Observations & 50,368 & 50,368 \\
\hline R-squared & 0.012 & 0.012 \\
\hline AdjR2 & 0.0119 & 0.0120 \\
\hline $\mathrm{F}$ & 27.20 & 37.01 \\
\hline \multicolumn{3}{|c|}{$\begin{array}{l}\text { Both regressions are ordinary least squares (OLS). }{ }^{* * *} \text { indicates significance at the } 1 \% \text { level, }{ }^{* *} \text { at the } \\
5 \% \text { level and }{ }^{*} \text { at the } 10 \% \text { level. Robust standard errors corrected for clustering at the country-year } \\
\text { level are presented under brackets. The sample consists of multinational group entities } \\
\text { (unconsolidated financial accounts) in } 19 \text { OECD countries over } 2000-10 \text {. The investment rate is } \\
\text { defined as the change in fixed assets (at book value), corrected for (book-value) depreciation and } \\
\text { divided by lagged fixed assets. Profit-shifting incentives are measured as the difference between the } \\
\text { statutory tax rate in the country of an entity and the average in the countries where its MNE group } \\
\text { operates (in line with Johansson et al., 2016a). }\end{array}$} \\
\hline
\end{tabular}

\section{Conclusion}

30. This study confirms the earlier finding that corporate taxes can reduce business investment (OECD, 2009). A 5 percentage point increase in the EMTR is associated with 5\% lower investment in the long term in the average industry. The tax sensitivity of investment is found to be influenced by taxplanning opportunities of MNEs. The investment of MNEs with the possibility to shift profits to lower-tax rate countries (or industries with a strong concentration of these MNEs) is found to be significantly less tax sensitive than the investment of other firms or industries. This result is obtained consistently at the industry and firm-level. In addition, strong anti-avoidance rules against tax planning are associated with a higher tax sensitivity of the investment of profit-shifting MNEs.

31. Overall, these results suggest that international tax planning reduces the effect of corporate taxes on investment and its location. However, this is achieved at the cost of additional distortions (e.g. uneven playing field between tax-planning MNEs and other firms) and increased uncertainty for firms and tax revenues as compared with a situation in which corporate tax rates were cut across the board (see Sorbe and Johansson, 2016).

32. This has implications for tax competition between countries. Empirical evidence suggests that tax competition took place in past decades, as countries have responded to lower corporate tax rates elsewhere by reducing their own rates (Devereux and Sorensen, 2006; IMF, 2014). Tax planning provides incentives for tax competition as countries compete to attract profits generated by MNEs' activities elsewhere. However, in the absence of tax planning, tax competition may not necessarily be less intensive (Keen, 2001; Peralta et al., 2006). This is because the sensitivity of investment to taxes may increase. For instance, the estimates in this paper suggest that the sensitivity of industry-level investment to the effective corporate tax rate would increase by about $30 \%$ if tax planning would be halved. 


\section{REFERENCES}

Arnold, J., B. Brys, C. Heady, A. Johansson, C. Schwellnus and L. Vartia (2011), "Tax Policy for Economic Recovery and Growth”, Economic Journal, Royal Economic Society, Vol. 121.

Auerbach, A., (1983), "Taxation, Corporate Financial Policy and the Cost of Capital", Journal of Economic Literature, Vol. 21, No. 3.

Becker, J. and N. Riedel (2012), "Cross-border tax effects on affiliate investment: Evidence from European multinationals", European Economic Review, Vol. 56.

Caballero, R. (1999), “Aggregate investment”, in John B. Taylor and Michael Woodford, eds., Handbook of macroeconomics, Vol. 1B, Amsterdam: Elsevier.

Desai, M., F. Foley and J. Hines (2005), "The demand for tax haven operations", Journal of Public Economics, Vol. 90.

Devereux, M. and Griffith, R. (2003), "Evaluating Tax Policy for Location Decisions", International Tax and Public Finance, Vol. 10, No 2.

Devereux, M. and P. Sorensen (2006), "The Corporate Income Tax: International Trends and Options for Fundamental Reform”, European Commission Economic Papers, No. 264.

Dharmapala, D. (2014), "What do we know about base erosion and profit shifting? A review of the empirical literature", CESifo Working Paper, No. 4612.

Djankov, S., T. Ganser, C. McLiesh, R. Ramalho and A. Shleifer (2010), "The Effect of Corporate Taxes on Investment and Entrepreneurship", American Economic Journal: Macroeconomics, Vol. 2, No. 3.

European Commission (2013), "Corporate taxation and the composition of capital", Quarterly report on the euro area, Vol. 12, Issues 4.

Fatica, S. (2013), "Do corporate taxes distort capital allocation? Cross-country evidence from industrylevel data", European Economy Economic Papers, No. 503, European Commission.

Feld, L. and J. Heckemeyer (2011), "FDI and Taxation: A Meta-Study", Journal of Economic Surveys, Vol. 25, No. 2.

Gal, P. (2013), "Measuring Total Factor Productivity at the Firm Level using OECD-ORBIS", OECD Economics Department Working Papers, No. 1049, OECD Publishing.

Gilchrist, S. and E. Zakrajsek (2007), "Investment and the cost of capital: New evidence from the corporate bond market", NBER Working Paper, No. 13174.

Grubert, H. and H. Slemrod (1998), "The effect of taxes on investment and income shifting to Puerto Rico", Review of Economics and Statistics, Vol. 80.

Grubert, H. (2003), "Intangible Income, Intercompany Transactions, Income Shifting, and the Choice of Location", National Tax Journal, Vol. 56, No. 1.

Hajkova, D., G. Nicoletti, L. Vartia and K. Yoo (2006), "Taxation and Business Environment as Drivers of Foreign Direct Investment in OECD Countries”, OECD Economic Studies, No. 43/2. 
Hall, R., and D. Jorgenson (1967), "Tax Policy and Investment Behavior", American Economic Review, Vol. 57.

Hassett, K. and R. Hubbard (2002), "Tax Policy and Business Investment", Handbook of Public Economics, Volume 3, ed. A. Auerbach and M. Feldstein, Amsterdam, North-Holland.

Hong, Q. and M. Smart (2010), "In praise of tax havens: International tax planning and foreign direct investment", European Economic Review, Vol. 54.

IMF (2014), "Spillovers in International Corporate Taxation", IMF Policy Paper, International Monetary Fund.

Johansson Å., Skeie Ø., S. Sorbe and C. Menon (2016a), "Tax planning by multinational firms: firm-level evidence from a cross-country database", OECD Economics Department Working Papers No. 1355, OECD Publishing.

Johansson Å., Skeie Ø. and S. Sorbe (2016b), “Anti-avoidance rules against international tax planning: a classification”, OECD Economics Department Working Papers No. 1356, OECD Publishing.

Jorgenson, D. (1963), “Capital Theory and Investment Behavior”, American Economic Review, Vol. 53, No. 2.

Keen, M. (2001), "Preferential regimes can make tax competition less harmful", National Tax Journal, Vol. 54, No. 4.

Menon, C. (2016), “An algorithm to identify multinational groups in ORBIS”, forthcoming.

Nickell, S. (1981), "Biases in dynamic models with fixed effects", Econometrica, Vol. 49, No 6.

OECD (2009), "Taxation and Economic Growth", Economic Policy Reforms, Going for Growth, Chapter 5, OECD Publishing.

OECD (2013), Action Plan on Base Erosion and Profit Shifting, OECD Publishing.

Overesch, M. (2009), "The Effects of Multinationals' Profit Shifting Activities on Real Investments", National Tax Journal, Vol. 62, No. 1.

Peralta, S., X. Wauthy and T. van Ypersele, (2006), "Should countries control international profit shifting?", Journal of International Economics, Vol. 68.

Pinto Ribeiro, S., S. Menghinello and K. Backer (2010), "The OECD ORBIS Database: Responding to the Need for Firm-Level Micro-Data in the OECD", OECD Statistics Working Papers, No. 2010/01, OECD Publishing. http://dx.doi.org/10.1787/5kmhds8mzj8w-en

Ragoussis, A. and E. Gonnard (2012), “The OECD-ORBIS Database - Treatment and Benchmarking Procedures", OECD mimeo.

Roodman, D. (2009), "How to do xtabond2: An introduction to difference and system GMM in Stata", The Stata Journal, Vol. 9.

Sharpe, S. and G. Suarez (2014), "The insensitivity of investment to interest rates: Evidence from a survey of CFOs" Finance and Economics Discussion Series, Divisions of Research \& Statistics and Monetary Affairs, Federal Reserve Board, Washington, D.C. 


\section{ECO/WKP(2016)85}

Skeie Ø. (2016), "International differences in corporate taxation, foreign direct investment and tax revenues", OECD Economics Department Working Papers No. 1359, OECD Publishing.

Sorbe S. and Å. Johansson (2016), "International tax planning, competition and market structure", $O E C D$ Economics Department Working Papers No. 1358, OECD Publishing.

Vartia, L. (2008), "How do Taxes Affect Investment and Productivity?: An Industry-Level Analysis of OECD Countries", OECD Economics Department Working Papers, No. 656, OECD Publishing.

Ziliak, J. (1997), "Efficient estimation with panel data when instruments are predetermined: An empirical comparison of moment-condition estimators", Journal of Business and Economic Statistics, Vol. 15. 


\section{APPENDIX 1: ROBUSTNESS CHECKS}

Table A1.1 Estimation with system GMM:

\begin{tabular}{|c|c|c|c|c|}
\hline & (1) & $(2)$ & (3) & (4) \\
\hline & \multicolumn{2}{|c|}{ Baseline } & \multicolumn{2}{|c|}{ With profit-shifting incentives } \\
\hline & OLS & System GMM & OLS & System GMM \\
\hline Dependent variable & \multicolumn{4}{|c|}{ Investment rate: $\mathrm{I}(\mathrm{t}) / \mathrm{K}(\mathrm{t}-1)$} \\
\hline Year dummies & yes & yes & yes & yes \\
\hline Country $\times$ industry fixed effects & yes & no & yes & no \\
\hline Lagged investment rate & $\begin{array}{c}0.578^{* * *} \\
{[0.036]}\end{array}$ & $\begin{array}{c}0.328^{* * *} \\
{[0.101]}\end{array}$ & $\begin{array}{l}0.577^{* * *} \\
{[0.0355]}\end{array}$ & $\begin{array}{c}0.329^{* * *} \\
{[0.101]}\end{array}$ \\
\hline $\begin{array}{l}\text { Lagged value-added growth (at country- } \\
\text { industry level) }\end{array}$ & $\begin{array}{l}0.027^{\star * \star} \\
{[0.007]}\end{array}$ & $\begin{array}{c}0.034^{\star * *} \\
{[0.009]}\end{array}$ & $\begin{array}{l}0.027^{\star \star *} \\
{[0.00726]}\end{array}$ & $\begin{array}{c}0.034^{\star * *} \\
{[0.009]}\end{array}$ \\
\hline $\begin{array}{l}\text { Lagged effective marginal tax rate } \\
\text { (EMTR) }\end{array}$ & $\begin{array}{l}-0.051^{* * *} \\
{[0.015]}\end{array}$ & $\begin{array}{l}-0.098^{* * *} \\
{[0.023]}\end{array}$ & $\begin{array}{c}-0.039^{* * *} \\
{[0.014]}\end{array}$ & $\begin{array}{l}-0.087^{\star \star \star} \\
{[0.023]}\end{array}$ \\
\hline $\begin{array}{l}\text { Lagged EMTR } \times \text { Number of MNEs with } \\
\text { profit-shifting incentives }\end{array}$ & & & $\begin{array}{c}0.126^{\star *} \\
{[0.057]}\end{array}$ & $\begin{array}{l}0.104 \\
{[0.073]}\end{array}$ \\
\hline Observations & 6,087 & 5,508 & 6,087 & 5,508 \\
\hline R-squared & 0.408 & & 0.409 & \\
\hline AdjR2 & 0.407 & & 0.407 & \\
\hline $\mathrm{F}$ & 34.11 & & 32.49 & \\
\hline Arellano-Bond test for $\mathrm{AR}(1)-\mathrm{p}$-value & & 0.000 & & 0.000 \\
\hline Arellano-Bond test for $\mathrm{AR}(2)-\mathrm{p}$-value & & 0.404 & & 0.408 \\
\hline Sargan-Hansen test - $p$ value & & 0.969 & & 0.859 \\
\hline
\end{tabular}

*** indicates significance at the $1 \%$ level, ${ }^{* *}$ at the $5 \%$ level and * at the $10 \%$ level. Robust standard errors corrected for clustering at the country-year level are presented under brackets. The sample consists of 29 industries in 28 OECD and G20 countries over 1997-2009. The system GMM estimations (columns 2 and 4) uses lagged levels and differences (lags 2 to 4 ) of the dependent variable as instruments. The model is estimated in Stata using the "xtabond2" command (Roodman, 2009). The Arellano-Bond test of serial correlation suggests that there is first order serial correlation in the disturbance term, but no second order serial correlation. The Sargan-Hansen test of over-identifying restrictions suggests that instruments are valid. OLS results are essentially unchanged when restricting the sample to the final system GMM sample. 
Table A1.2 Using the average rather than marginal effective tax rate:

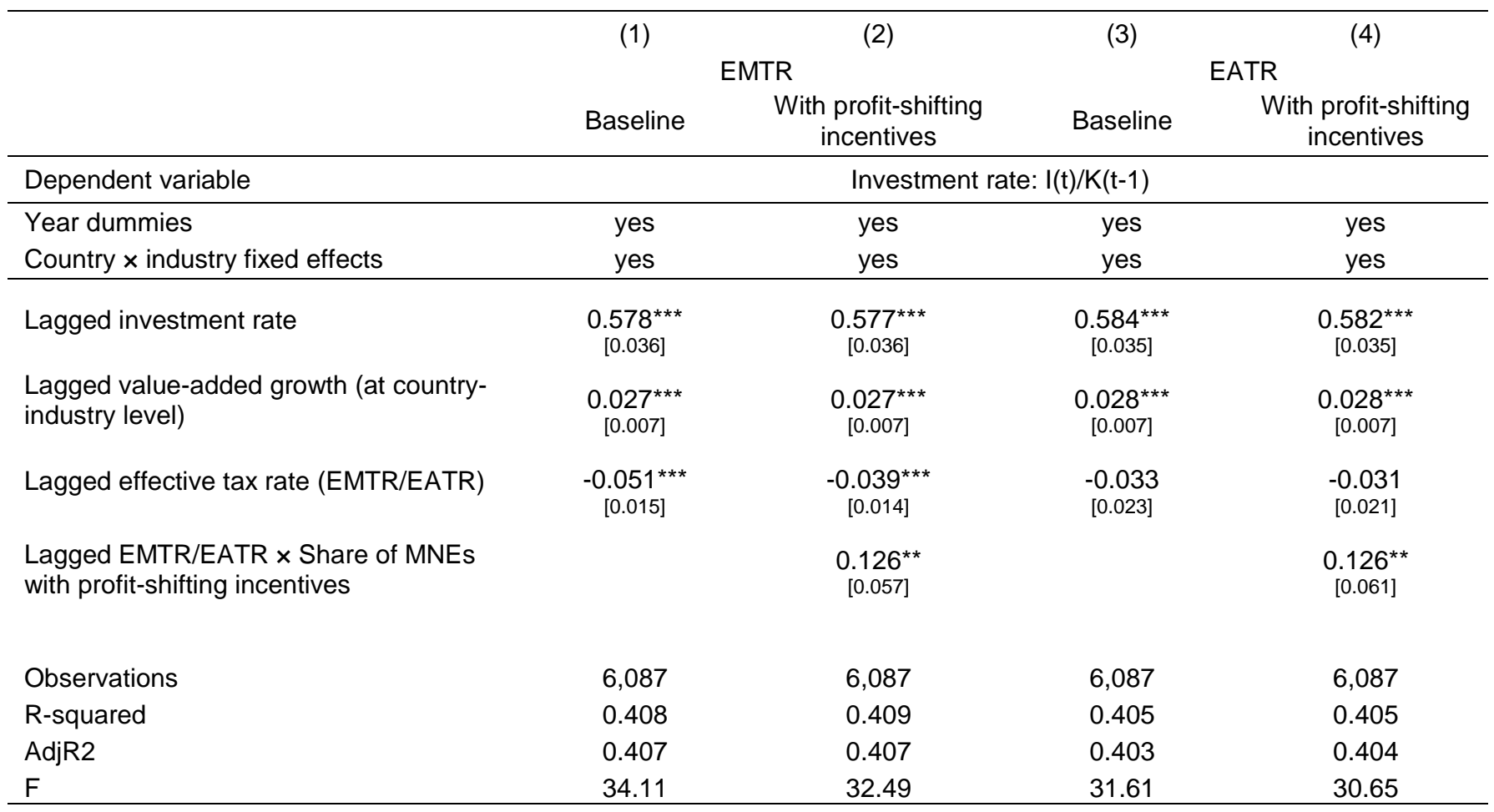

All regressions are ordinary least squares (OLS). ${ }^{* * *}$ indicates significance at the $1 \%$ level, ${ }^{* *}$ at the $5 \%$ level and ${ }^{*}$ at the $10 \%$ level. Robust standard errors corrected for clustering at the country-year level are presented under brackets. The interacted variables are mean-centred, so coefficients can be interpreted as the effects at the mean. The sample consists of 30 industries in 29 OECD and G20 countries over 19972009. Investment and value-added data is taken from the World Input-Output Database (WIOD). The forward-looking effective marginal and average tax rates (EMTR and EATR) are from the Oxford Centre for Business Taxation. The number of MNEs with profit-shifting incentives is extracted from ORBIS. Anti-avoidance strength is the classification presented in Johansson et al. (2016b). 